\section{Managing the all-volunteer force in a time of war}

Curtis J. Simon and John T. Warner

$I^{\mathrm{s}}$

September of 2003, the U.S. Department of Defense (DoD) sponsored a conference celebrating the 30th anniversary of the modern all-volunteer force 1 (AVF) in the United States. As a reading of the conference papers attests, speakers at this conference uniformly pronounced the AVF a success. ${ }^{1}$ After a rocky start to the AVF in the late 1970s, since 1980 the U.S. military services have met or exceeded their recruiting and retention goals in most years as measured by either the quantity or quality of personnel, and have done so at reasonable cost.

The ongoing conflict in Iraq is the U.S. military's first protracted conflict since the inception of the AVF. ${ }^{2}$ At the time of the conference, Operation Iraqi Freedom (OIF) was only six months old. The speakers were well aware that a protracted war might affect recruiting and retention adversely, and that recruiting and retention goals might be achievable only at very high cost. The first Gulf War was a major conflict in which over 400,000 U.S. military personnel were deployed to the Gulf region, but the war was short, beginning in August 1990 and ending in March 1991, a period too short to have any perceptible impact on recruiting or retention. From late 2002, the time that military personnel and prospective recruits could have begun to expect deployment to Iraq, until late 2006, the conflict is already four years old.

The long duration of this conflict raises a number of important questions. What impact has it had on U.S. military recruiting, retention, and manpower costs? Does the prolonged nature of the conflict make a return to the draft in the U.S. necessary or desirable? Is the cost of the volunteer force acceptable? This article provides brief answers to these questions as a starting point for the fuller discussions that will follow among economists, policymakers, and others interested in the state of the AVF in the United States.

\section{Overview of U.S. military forces}

It is useful to begin with some facts about the current size and geographic distribution of U.S. military forces and how they have changed over the past five years. Table 1 indicates that about 1.4 million personnel served on active duty in the U.S. military over the period 2001-2005. ${ }^{3}$ Over the period 2001-2004, the U.S. Army active duty force expanded by almost 20,000 personnel, but then fell by 8,000 in 2005. Congress authorized an increase in the Army's 2006 end strength to 512,000, and to 520,000 by the end of the decade. ${ }^{4}$ The Marine Corps also expanded, by 6,000, over the period. By contrast, the active Navy force fell by 16,000 over the period and will continue to contract in the future, as will the Air Force. ${ }^{5}$

About 850,000 Selected Reserve personnel - reservists who are attached to active
Table 1: U.S. military force levels, FY2001-2005 (in thousands)

$\begin{array}{lrrrrrr} & \underline{2001} & \underline{2002} & \underline{2003} & \underline{2004} & \underline{2005} \\ & 1,385 & 1,412 & 1,434 & 1,427 & 1,389 \\ \text { Total active duty personnel } & 481 & 487 & 499 & 500 & 492 \\ \quad \text { Army } & 378 & 383 & 382 & 373 & 362 \\ \quad \text { Navy } & 173 & 174 & 178 & 178 & 180 \\ \quad \text { Marine Corps } & 354 & 368 & 375 & 377 & 352 \\ \quad \text { Air Force } & 255 & 231 & 253 & 288 & 291 \\ \text { Total abroad non-OIF* force } & 0 & 0 & 184 & 171 & 193 \\ \text { Total OIF force** } & & & & & \\ & 18.4 & 16.4 & 30.5 & 32.2 & 34.8 \\ \text { Total abroad as \% of active force } & 103 & 104 & 104 & 101 & 82 \\ \text { Army abroad non-OIF force } & 0 & 0 & 153 & 102 & 132 \\ \text { Army OIF force** } & 21.4 & 21.4 & 51.5 & 40.6 & 43.4 \\ \text { Army abroad as \% of active force } & 43.0 & 67.7 & 170.5 & 170.1 & 157.0 \\ \text { Reserve and Guard mobilized*** } & 867.4 & 874.3 & 875.0 & 851.4 & 826.0 \\ \text { Selected Reserve personnel } & 5.0 & 7.8 & 19.5 & 19.4 & 19.0 \\ \text { Percent of Selected Reserve mobilized } & & & & & \end{array}$

* OIF: Operation Iraqi Freedom.

** Includes Reserve and National Guard personnel stationed in Iraq.

***Based on DoD press reports of number mobilized on dates closest to end of fiscal year.

Source: Directorate for Information, Operations and Reports, Washington

Headquarters Services, U.S. Department of Defense (annual reports, 2001-2005).

reserve or National Guard units - supplement the 1.4 million active duty personnel Another 300,000 individuals serve in the Individual Ready Reserve (IRR), individuals who have prior military service and are not associated with active reserve units, but who are available for call-up during a national emergency.

As a result of U.S. operations in Iraq, the number of personnel stationed abroad has expanded considerably since 2001. In 2001, the number stationed abroad was 18.4 percent of the active duty force. By 2005 this percentage had increased to about 35 percent. The U.S. Army has borne the brunt of U.S. deployments; the number of its personnel stationed abroad, including both active duty personnel and reservists, expanded from a number equal to 21 percent of the active force in 2001 to 43 percent in 2005. Almost 20 percent of the Guard and Reserve forces are now mobilized, compared with just 5 percent in 2001.

One of the big changes from the draft to the AVF in the United States has been a significant increase in the experience level of the force. ${ }^{6}$ The services use a variety of 
policy tools to manage and maintain the experience distribution of their forces. As U.S. military forces adjust to changes in size and losses from combat and normal turnover, they attempt to maintain balance with respect to experience. Inexperienced personnel tend to be less costly, but are less productive than experienced personnel. The optimal mix of personnel by experience varies by service and by occupation. Due to its technical nature, the Air Force staffs a more experienced force than the Army and Navy while the Marine Corps, with its emphasis on combat missions, prefers a younger force comprised largely of personnel in their first enlistment. Thus, in 2005 Air Force enlisted personnel averaged 8.6 years of experience, Marine Corps 4.8 years, the Army 6.3 years, and the Navy 6.8 years. ${ }^{7}$

\section{Overview of factors affecting recruiting and retention in the U.S. military}

Staffing a volunteer military force of the size and geographic distribution of the U.S. military is a daunting challenge. In a volunteer system, successful recruitment and retention must attract the requisite number and quality of individuals away from competing civilian alternatives. This means offering sufficiently attractive pecuniary returns such as current and deferred monetary compensation and benefits such as health care, and non-pecuniary returns such as working conditions and pride of service. In the case of the U.S. military, direct current compensation includes basic pay, allowances for food and housing, special and incentive (S\&I) pays such as enlistment and re-enlistment bonuses, sea pay, and hazardous duty pay. The primary components of deferred compensation are retirement and health care benefits (in the United States, limited to those with 20 or more years of service) and education benefits, which are available for virtually all veterans. ${ }^{8}$

To give readers an indication of how well U.S. military personnel are paid, Table 2 shows Regular Military Compensation (RMC) for 2000 and 2006, stated in 2006 dollars. RMC is the salary equivalent of military compensation and includes basic pay, allowances for food and housing, and a tax advantage resulting from the nontaxability of the allowances. In 2006, enlisted RMC averaged $\$ 44,300$ while officer RMC averaged $\$ 87,500$. RMC grew substantially in real terms, 13.1 percent overall, from 2000 to 2006 for reasons discussed below. In both 2000 and 2006, S\&I pays averaged about 10 percent of basic pay.

Military service, by its nature, is not just another job. The work is arduous in peace and exhausting and dangerous in war. Beyond physical danger, military work is often mentally stressful, both on the military member and the military member's family, particularly when the service member is posted abroad. Encouraging enlistments in such an environment requires not only making potential recruits aware of opportunities in the military but, perhaps more importantly, shaping the attitudes of youth and their parents about the importance and value of military service. To provide information about military career opportunities and shape attitudes about military service, the military services spent $\$ 450$ million on enlisted advertising in 2005. Over
Table 2: Elements of direct military compensation, 2000 and 2006

\begin{tabular}{|c|c|c|c|c|c|c|}
\hline & \multicolumn{2}{|c|}{ Enlisted } & \multicolumn{2}{|c|}{ Officer } & \multicolumn{2}{|c|}{ Total } \\
\hline & $\underline{2000}$ & $\underline{2006}$ & $\underline{2000}$ & $\underline{2006}$ & $\underline{2000}$ & $\underline{2006}$ \\
\hline Basic pay (\$) & 23,671 & 26,100 & 56,881 & 61,500 & 28,853 & 31,800 \\
\hline Allowances (\$) & 13,207 & 15,600 & 15,775 & 20,500 & 13,640 & 16,300 \\
\hline Tax advantage (\$) & 2,426 & 2,600 & 4,769 & 5,500 & 2,781 & 3,100 \\
\hline RMC (\$) & 39,304 & 44,300 & 77,425 & 87,500 & 45,273 & 51,200 \\
\hline Real BP growth (\%) & & 10.3 & & 8.1 & & 10.2 \\
\hline Real RMC growth (\%) & & 12.7 & & 13.0 & & 13.1 \\
\hline Incentives as \% of BP & 7.6 & 9.4 & 12.3 & 10.8 & 9.9 & 9.8 \\
\hline Avg. incentive amount (\$) & 1,799 & 2,453 & 6,996 & 6,642 & 2,856 & 3,116 \\
\hline
\end{tabular}

Note: BP - basic pay; RMC - regular military compensation. Source: see Table 1.

the past five years, the total DoD enlisted recruiting budget, including advertising, recruiter costs, and enlistment incentives such as bonuses and college benefits, has averaged about $\$ 2.5$ billion per year. ${ }^{9}$

The compensation bundle will naturally need to vary as the supply of manpower to the military changes relative to the demand. For example, for any given bundle of compensation and other amenities, recruitment and retention are easier during civilian business cycle downturns. Recruiting and retention become more difficult during cyclical upswings due to the wider availability of civilian jobs and higher civilian wages. The sensitivity of recruitment and retention to the state of the civilian economy has been a constant source of concern to U.S. military manpower planners over the course of the AVF period.

Since the advent of the AVF, the U.S. military has placed great importance on attracting high-quality recruits. Operationally, this means youth who have graduated from high school and score better than average on the Armed Forces Qualification Test (AFQT).${ }^{10}$ Long-term trends and short-term business cycle fluctuations affect the supply of such recruits. Two key long-term trends have been the rising return to a college degree and the decline in military veterans in the U.S. population. The former has increased the fraction of high school graduates who attend college, and hence reduced the supply of high-quality military recruits. The latter form an important component of so-called "influencers." The decline in their numbers - those from World War II formed the largest contingent - has negatively affected recruiting. ${ }^{11}$ Another long-term trend factor is the changing demographic composition of the U.S. youth population. In particular, Hispanics are the fastest-growing component of the 
youth population. This trend has both positive and negative implications for military recruiting. On the positive side, surveys indicate that Hispanics are more inclined than other groups to join the military. On the negative side, Hispanics are less likely to meet entry standards.

\section{U.S. military recruiting, 1995-2005}

In the late 1980s, the U.S. military recruited about 280,000 youth per year for the enlisted ranks. Between 1990 and 1994, the U.S. military forces were reduced by about one-third, from about 2.1 to 1.4 million active-duty personnel, and annual recruiting goals declined to about 180,000 . High-quality youth, as defined above, form the target population. This section examines the success of U.S. military recruiting in this period.

To interpret recruiting trends, it is necessary to understand the size and characteristics of the recruiting market in the United States. There are about 30.7 million youth, both male and female, in the United States between the ages of 18 and 24 , the prime age range for military recruiting. Not all of these youth are eligible to serve in the U.S. military. In fact, only about 26 percent of them meet current entry standards. ${ }^{12}$ Reasons for failure to meet minimum entry standards (with their percentages in the youth population in parentheses) include alcohol or drug abuse (17), medical or physical disqualification (39), moral reasons (9), dependents (6), and a score of less than 15 on the AFQT (3).

The population meeting minimum standards is around 8 million. This population consists of four groups, namely college graduates (2 percent of the youth population), those enrolled in college (11 percent), high-school degree graduates not enrolled in college and who would score 50 or above on the AFQT (3 percent), and high school non-graduates and those who would not score above 50 on the AFQT (10 percent). The "high-quality" market consists of the first three groups of youth meeting minimum entrance standards, about 4.9 million youth, while the "low-quality" market is comprised of those in the fourth group, about 3.1 million.

How well have the military services recruited over the decade 1995-2005? Enlistments of roughly 180,000 per year correspond to about 4 percent of the qualified population of 4.9 million. Figure 1 shows non-prior service high-quality enlistments - high school diploma graduates who score 50 or above on the AFQT - as a fraction of total enlistments for the period $1995-2005 .{ }^{13}$ Since roughly 63 percent of recruits over this period were high-quality (about 113,000 per year), high-quality enlistments comprised about 2.3 percent of the high-quality youth population while low-quality enlistments (about 67,000 per year) comprised about 2.2 percent of the low-quality qualified population. High-quality enlistments are about 7.4 percent of the highquality non-college population. However, males account for over 80 percent of enlistments; therefore, DoD must recruit about 12 percent of qualified high-quality, non-college males, compared with just 3 percent of females.

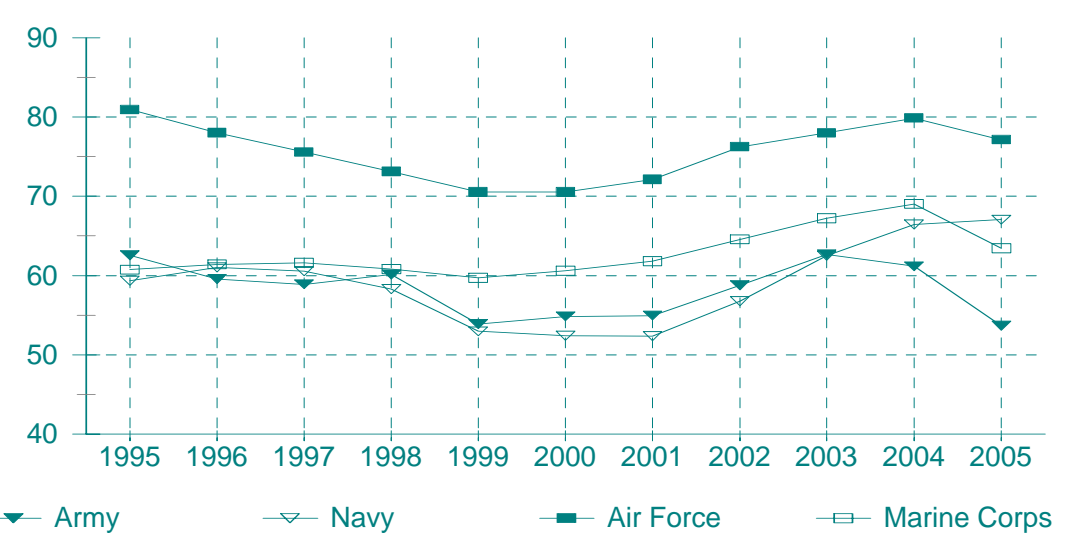

Figure 1: High-quality enlistments as percent of total enlistments, FY19952005.

While DoD uses the terms high-quality and low-quality to describe its recruits, it should be borne in mind that all recruits must meet stringent moral, physical, and education standards. Since 1985, over 90 percent of recruits in every year possessed a high school degree, compared with 81 percent in the population of youth aged 1824 . Most recruits who are defined to be low quality possess a high school degree. The military services take very few recruits who neither possess a high-school degree nor score 50 (average) or better on the AFQT.

Figure 1 reveals significant differences in high-quality intake across services as well as differences over time within services. The Air Force has historically attracted more high-quality recruits with fewer recruiting resources than the other services. ${ }^{14}$ Percent high-quality in the Air Force over the 1995-2005 period ranged between 70 and 80 percent followed by, for most of the period, the Marine Corps. Prior to 2003, the Army and Navy exhibit similar high-quality percentages by year, and similar fluctuations in this percentage over time.

The Army has experienced significant swings in the number of enlistment contracts signed over the decade. In 1995, 71,000 individuals signed enlistment contracts, of which 44,400 were high-quality. Total enlistments grew for several years, and then fell in the late 1990s before peaking at 92,600 in 2002. Total enlistments contracted to just 68,400 in 2005. In some periods, such as 2000-2002, high and low-quality enlistments moved together. But in periods of recruiting difficulty, such as the late 1990s and 2004-2005, the Army substituted low-quality recruits for high-quality recruits when high-quality recruits became more difficult to attract. Most of the quality substitution over time has come from substituting recruits who possess high-school degrees but do not score above 50 on the AFQT for highschool graduates who score above 50. In fact, over 90 percent of Army recruits 
possessed a high-school degree in every year between 1985 and 2004. But that percentage dipped to 87 percent in 2005.

Figure 1 illustrates the sensitivity of U.S. military recruiting to the state of the economy. The U.S. economy expanded sharply in the mid-to-late 1990s, and by 2000 the civilian unemployment rate was 30 percent lower than in 1995, falling from 5.6 percent to 3.9 percent. As is evident in Figure 1, this expansion was associated with declining recruit quality in all four services. But the U.S. economy dipped into recession in 2001, and the unemployment rate rose by 50 percent over the period 2000-2003 (3.9 percent to 6 percent). Not unexpectedly, recruiting in all four services improved during this period. The increase might also reflect a supply response to the events of 9/11 and their aftermath. Between 2004 and 2005, quality levels dropped in three of the four Services. The percent high-quality also fell in the Army between 2003 and 2004 as well, to a level not seen since 1989, and before that, 1985. The most recent quality declines reflect, at least in part, a recovering civilian economy, with unemployment declining from 6.0 percent in 2003 to 5.1 percent in 2005. ${ }^{15}$

It is tempting to blame the Iraq war for the recent drop in quality in the Army and Marine Corps, which have borne disproportionate casualty burdens. More will be said about the effects of the war on the Army below. But the Army's high-quality decline occurred prior to the Marine Corps decline and begs the question why. One reason may lie in management of the Army's recruiter force. At the start of FY2002, the Army had about 6,100 recruiters. Although the reasons are not entirely clear, the Army made a deliberate policy decision to reduce its recruiter force. The recruiter force fell steadily for the next seven quarters, and bottomed out at 4,400 recruiters in the last quarter of 2004. During 2005 the Army restored about two-thirds of this reduction (from 4,400 to 5,500 ).

Some observers worry that the military recruits are drawn disproportionately from less educated, lower income groups in American society. They mention, in particular, the apparent dearth of college-bound youth in the military. Indeed, youth from states with higher fractions of college-bound youth, more densely populated areas, and youth from higher-income zip codes are somewhat less likely to enlist. Figure 2 provides evidence on propensity to serve and family income for the Army, Navy, and Marine Corps. ${ }^{16}$ The figure shows the cumulative percentage of enlistments from each income decile. If youth living in each income decile were equally likely to serve, the cumulative percentages would all lie along the 45-degree line. The cumulative percentages are, in fact, bowed out, indicating that individuals from lower-income zip codes are more likely to enlist. The distribution of recruits was most representative in the Marine Corps, followed by the Navy and Air Force (not shown, but similar to the Navy), and Army. Even in the Army, 40 percent of the recruits are from zip codes in the top half of the income distribution, and 20 percent of recruits are from zip codes in the top 30 percent.

One of the big changes in Army recruiting over the FY1995-2005 decade has been in its racial composition. Blacks have historically represented a larger share of Army

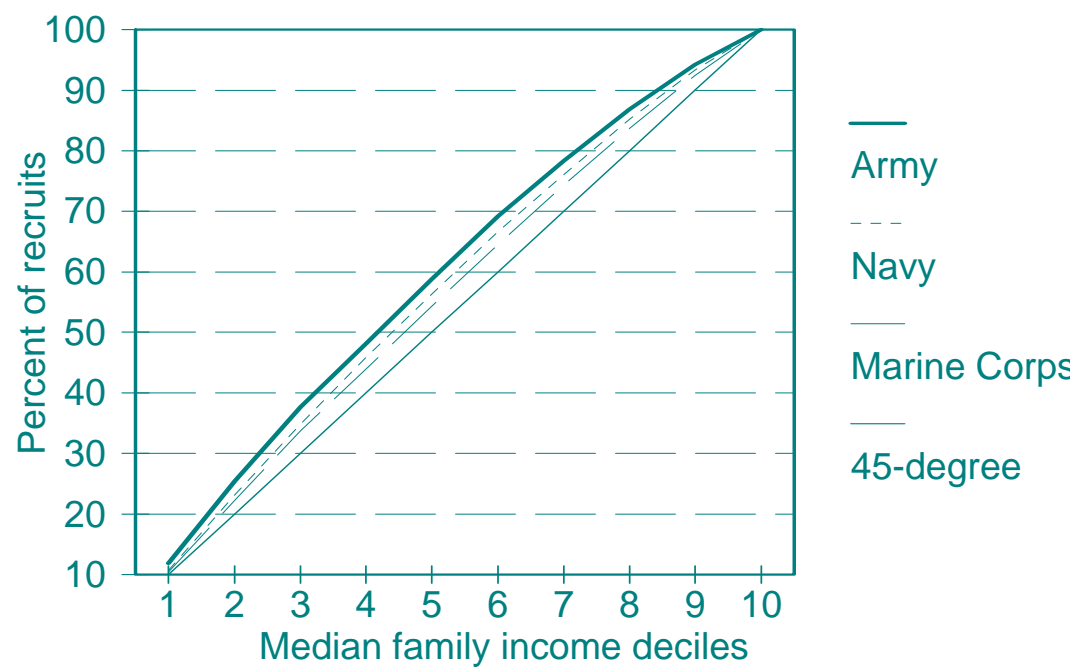

Figure 2: Cumulative distribution of recruits by family income decile in recruit's 5-digit zip code.

recruits than their share of the U.S. population. Indeed, between 1995 and 2000, black recruits made up about 22 percent of total Army enlistments. This percentage began declining in 2001, and by 2005 the black share of total Army recruits had declined to 14 percent, their overall share in the population. By way of contrast, Hispanic recruits have grown steadily, from just 7 percent in 1995 to about 13 percent in 2005, also about equal to their population share. The white share declined gently between 1995 and 1999 from about 67 percent to 62 percent, and then began rising, standing at just under 70 percent by 2005 .

We conclude our overview of recruiting by highlighting recruiting for the U.S. reserve forces. The United States has a Selected Reserve force of around 850,000 personnel. Reserve units recruit both non-prior service and prior service personnel. For example, between 2000 and 2005, the two Army reserve components (Army Reserve and Army National Guard) recruited an average of 98,000 people. ${ }^{17}$ Combined, these components recruited more than the active Army force. Until very recently, the reserve forces of the various services have almost always met or exceeded their annual recruiting targets. But despite meeting recruiting goals in earlier years, the two Army reserve components recruited only 81,000 personnel in 2004 and 78,000 personnel in 2005, well short of their combined goal..$^{18}$ But despite these shortfalls, Army reserve component recruiting rebounded dramatically in 2006, with these two components bringing in 103,000 new personnel. ${ }^{19}$ 


\section{Estimating the recruiting effect of Operation Iraqi Freedom}

What has been the effect of the ongoing Iraq conflict on recruiting? A complete analysis for all four services is beyond our current scope. However, we have data sufficient to allow us to begin to answer this question for the Army. We estimated models of high-quality enlistment supply using data over the period 1996 through 2005. The data are at the state level at a quarterly frequency. To account for the sizeable differences in population across states, the dependent variable is defined as the (natural log of) the number of high-quality enlistments per youth in a state.

Two explanatory variables capture the effects of the civilian economy: the rate of civilian unemployment and relative military monetary compensation. ${ }^{20}$ We measure the intensity of the recruiting effort using information on the size of the recruiter force and recruiting goals assigned to each state at each point in time. Since more experienced recruiters are more productive than less experienced ones, we allow the effects of increases in the size of the recruiter force to have a different magnitude effect than decreases. ${ }^{21}$

We measure the effects of the Iraq war using three variables. First, we use an indicator variable that takes a value of one during the Iraq war period and zero otherwise. Secondly, we include the number of deaths in all four services in a given quarter, measured in 100s. Finally, we have included a variable that is intended to measure the attitudes in each state toward the Iraq conflict, which we measure as the percent of the population that voted for George W. Bush in the 2004 election. Although estimation over longer time periods will enhance the precision of the estimated effects of the various explanatory variables, it is only over the shorter time period over which one might expect to see the effects of attitudes regarding the Iraq war. $^{22}$

Table 3 reports estimates of the model for two time periods: 1996-2005 and 20042005. The estimates for the long time period indicate that each 10 percent increase in pay raises high-quality enlistment by 7 percent. The short-period estimated effect is somewhat larger, but we view it with some caution due to the limited observation period. The long-period estimates suggest that each 10 percent increase in the civilian unemployment rate increases high-quality enlistments by 4.2 percent. (The estimated coefficient on unemployment over the short period is positive, but small in magnitude. This is not surprising in light of the shortness of the period analyzed.) Each 10 percent increase in the size of the recruiter force is estimated to increase high-quality enlistments by 4.8 percent. The estimated effect of a 10 percent decrease in the size of the recruiter force over the long period is somewhat larger at 6.2 percent, and is consistent with the notion that experienced recruiters are more productive. The estimates for the short period tell a qualitatively similar story.

We now turn to the estimated effects of the Iraq war. Focusing on the longer time period, the estimated effect of the war in the first year is obtained by adding the coefficient on the dummy variable and trend, or about -0.01 , a negligible effect.
However, the estimates indicate that recruiting fell by 25 percent each year thereafter. The impact of the Iraq war using the estimates for the short period is obtained by adding together the effects of the OIF and Bush percentage trends. Assuming that the average vote for Bush was (roughly) 50 percent, each year of the Iraq war was associated with a 33.7 percent decline in h i g h - q u a l i t y enlistments. $^{23}$ The trend is less negative in states that had higher votes for Bush, and more negative in states with higher votes for John Kerry, his Democratic Party opponent. Finally, we consider the impact of casualties. The shortperiod estimate of the effect of fatalities is

small because there was limited variation in this variable over the estimation period. However, the estimated effect of fatalities over the longer period indicates that each additional 100 casualties per quarter (400 per year) reduce high-quality enlistment supply by 6.2 percent.

\section{Retention in the $1995-2005$ period}

Retention is continually managed in different career zones to maintain a force that is

balanced by rank and experience level. Management tools include manipulation of

Table 3: Regressions for Army high-quality enlistments

$\begin{array}{lll}\text { Independent variable } & 1996-2005 & 2004-2005 \\ \text { Relative military pay } & 0.704 & 1.065 \\ & (4.05) & (3.51) \\ \text { Unemployment rate } & 0.420 & 0.075 \\ & (9.77) & (0.58) \\ \text { Army recruiters (+) } & 0.476 & 0.483 \\ & (8.32) & (3.65) \\ \text { Army recruiters (-) } & 0.621 & 0.605 \\ & (12.68) & (6.81) \\ \text { Army goal } & 0.068 & 0.235 \\ & (3.30) & (2.44) \\ \text { OIF period dummy } & 0.246 & 0.300 \\ & (10.71) & (7.29) \\ \text { OIF deaths (100s) } & -0.062 & -0.023 \\ & (2.12) & (0.56) \\ \text { Overall trend } & 0.007 & - \\ & (0.17) & \\ \text { OIF period trend } & -0.262 & -0.457 \\ & (14.51) & (5.98) \\ \text { 2004 Bush pct trend } & -0.002 & 0.240 \\ & (0.03) & (1.91) \\ \text { Number of observations } & 1950 & 350 \\ \text { R-square } & 0.364 & 0.338\end{array}$

Note: Numbers in parentheses are t-statistics. 
elements of compensation such as basic pay and reenlistment bonuses and personnel policies such as mandatory separation (up-or-out) points that vary by rank and experience. Over the last decade, the services have generally very successfully managed retention to achieve desired force outcomes. ${ }^{24}$

One period of concern, though, was the late 1990s, when the hot civilian labor market began to impinge on retention, particularly in high-tech occupations. Following recommendations of the 9th Quadrennial Review of Military Compensation, Congress implemented a series of increases in basic pay that began in July of 2000. The combined effects of these increases were shown in Table 2, which revealed that real basic pay and RMC have risen around 10 and 14 percent, respectively, since 2000 . The basic pay increases that were implemented in the years 2000-2003 gave personnel in the mid and senior ranks larger percentage increases than personnel in the junior ranks. These pay increases were purposely designed to maintain retention in the mid and upper ranks and increase motivation and performance in the lower ranks.

These basic pay increases were implemented in a time of peace before the U.S. became involved in operations in Afghanistan and Iraq. Most of the special and incentive (S\&I) pay increases have occurred since the inception of the conflict in Iraq and have played an important role in retaining personnel beyond the initial enlistment. In fact, voluntary retention has increased since 2000. In 2000, for example, 21,400 Army personnel reenlisted after completing their initial enlistment. In 2005 and 2006, the Army more than met its goals for initial reenlistments, re-signing 27,800 and 28,000 , respectively. It also met or exceeded its goals for reenlistments of personnel beyond the initial reenlistment point. In the Army's case, reenlistments were bolstered by a bonus of $\$ 15,000$ for reenlistments of personnel stationed in Iraq and Afghanistan. ${ }^{25}$ Marine Corps reenlistments have exceeded goals in every year since 2000. ${ }^{26}$ Attrition from Selected Reserve units has fallen since 2000.

It might be surprising to some that retention has remained strong in the face of the stress and the risks of injury or death placed on personnel deployed to the combat zones, the stress to their families, and the extra workloads placed on personnel not deployed. That retention has not declined in the face of this wartime situation is testimony to the dedication of the men and women in the U.S. armed forces - both active and reservist - and to the effectiveness of the improvements in compensation that have compensated for the extra demands on personnel. ${ }^{27}$ Concern of course remains that the retention levels that have prevailed in the Army, Marine Corps, and Selected Reserve units since 9/11 cannot be sustained over the longer term if the deployment rates shown in Table 1 do not soon decline.

High deployment rates can of course be alleviated by increases in end strength. Congress has authorized the Army to grow to 520,000 personnel by 2010, and many believe that the Marine Corps needs to grow beyond its currently authorized strength of 180,000 . An expansion in force size raises the issue of cost. Despite large pay increases since 2000 and increases in cost due to the mobilization of large numbers of reservists, manpower costs as a percentage of the DoD budget have declined, from 27.3 percent in 2000 to 24.1 percent in 2005. But manpower costs have risen by $\$ 32$ billion, from 0.75 percent in 2000 to 0.97 percent in $2005 .{ }^{28}$ Even with the rise from 2000 to 2005, manpower costs are a smaller percentage of GDP than they were in any year during the Cold War era. A return to the active duty force level that prevailed in the Cold War era of 2.1 million - well beyond levels currently contemplated by policymakers - would raise personnel costs as a percent of GDP to at most 2 percent, the personnel cost share of GDP in $1975 .^{29}$

While the rising cost of military manpower is a matter of concern, the notion that personnel costs are inordinate, either in terms of the ability to pay for them or in terms of what was paid in the past, is not supported by the facts. ${ }^{30}$

Options for expanding the force

A number of observers believe that the size of the U.S. armed forces is too small to meet current commitments or future contingencies. This concern is focused on the Army and, to a lesser extent, the Marine Corps. The prospect of attracting additional Army and Marine Corps volunteers has led some to balk at the cost and to propose conscription as a way of filling military manpower requirements.

It is easy to exaggerate the cost-savings of conscription. No proposal for a draft envisions an enlistment commitment of more than two years. Thus, any cost savings are limited to the first two years of service. More importantly, draftees are far less likely to reenlist than are volunteers. Consider an expansion in the size of the Army enlisted force from its current level of 405,000 to 505,000. How many more recruits would be needed? How would the experience distribution of the force be affected? How much would this expansion cost? To begin to answer these questions, we constructed four steady-state force scenarios based on average FY2000-2005 Army enlisted continuation rates and computed, to a first order of magnitude, their costs.

Table 4 shows the resulting computations. Based on the current force level of 405,000 , which costs $\$ 10.5$ billion in basic pay per year, the Army must enlist 81,400 recruits annually. This force costs $\$ 21.5$ billion including costs for recruiting and training. Assuming no changes in continuation behavior, expanding the Army force by 100,000 would require enlisting an additional 19,100 volunteers per year, at an additional basic pay cost of $\$ 2.6$ billion and a total direct cost of $\$ 28.1$ billion. To attract these additional personnel without reducing the Army’s quality mix, we increase the recruiter force by 50 percent and double the special and incentive pays budget (which includes enlistment and reenlistment bonuses).

We consider two draft scenarios. Both scenarios assume that draftees serve for two years and then depart military service, while volunteers display the same continuation behavior as currently. In the first scenario, the Army continues to enlist 81,400 volunteers, and drafts a number sufficient to achieve its desired end strength of 505,000, which we calculate to be 61,500. Notice that the Army must access and train 
Table 4: Costs of expansion options for the army

\begin{tabular}{|c|c|c|c|c|}
\hline & $\begin{array}{l}\text { Current } \\
\text { force }\end{array}$ & $A V F$ & $\begin{array}{l}\text { Small } \\
\text { draft }\end{array}$ & $\begin{array}{l}\text { Large } \\
\text { draft }\end{array}$ \\
\hline End strength & 405,000 & 505,000 & 505,000 & 505,000 \\
\hline Voluntary accessions & 81,400 & 101,500 & 81,400 & 60,000 \\
\hline Draftees & - & - & 61,500 & 127,000 \\
\hline Percent careerists & 48 & 48 & 38 & 28 \\
\hline Basic pay cost & $\$ 10.5$ & $\$ 13.1$ & $\$ 12.4$ & $\$ 11.5$ \\
\hline RMC cost & $\$ 17.8$ & $\$ 22.3$ & $\$ 21.0$ & $\$ 19.6$ \\
\hline S\&I cost & $\$ 1.5$ & $\$ 3.0$ & $\$ 1.9$ & $\$ 1.0$ \\
\hline Recruiting cost ${ }^{\mathrm{a}}$ & $\$ 0.6$ & $\$ 0.8$ & $\$ 0.6$ & $\$ 0.4$ \\
\hline Training cost ${ }^{\mathrm{b}}$ & $\$ 1.6$ & $\$ 2.0$ & $\$ 2.9$ & $\$ 3.7$ \\
\hline Direct force cost & $\$ 21.5$ & $\$ 28.1$ & $\$ 26.4$ & $\$ 25.2$ \\
\hline Direct cost differential & - & - & $-\$ 1.7$ & $-\$ 3.4$ \\
\hline
\end{tabular}

All costs are in billions of dollars. ${ }^{a}$ Recruiters and advertising. ${ }^{\mathrm{b}}$ Assumes training cost of $\$ 20,000$ per recruit.

about 147,000 individuals per year under this scenario, more than 40 percent more than required with the expanded AVF force. Training costs rise by $\$ 0.9$ billion relative to the expanded AVF scenario, assuming training costs of $\$ 20,000$ per recruit. ${ }^{31}$ Importantly, careerists as a fraction of the total force decline from 48 to 38 percent. The second scenario envisions reducing voluntary accessions to just 60,000 per year. Now the Army must draft 127,000 individuals per year! We allow the Army to reduce its recruiter force and eliminate its enlistment bonus budget - hence the decline in recruiting and S\&I costs. This mixed force has just 28 percent careerists.

These calculations suggest minor budgetary differences between the expanded voluntary force and the two mixed forces. Of course, economic theory suggests that forces should be compared on the basis of their real resource costs and not just their budgetary costs. The two conscripted forces have higher opportunity costs than the mixed forces. ${ }^{32}$ As Poutvaara and Wagener elaborate elsewhere in this issue, conscription brings other costs, including those related to youths' attempts to evade conscription and the government's efforts to prevent it. Once all costs are considered, it is likely that, over the range of likely force sizes in the United States in the foreseeable future, the social costs of conscripted forces will exceed the social costs of a volunteer force. ${ }^{33}$ Furthermore, for the cost comparisons to be complete, one needs to compare the costs of equally capable forces; it is likely that the mixed forces in our scenarios would be less effective than the expanded volunteer force owing to the significant drop in their average experience levels. Less experienced personnel are generally less productive, and the decline in productivity is more pronounced the more technologically advanced the force. Adjustment for productivity differences would further increase the relative costs of the conscripted forces.

Some critics of the AVF argue for a draft on the ground that high ability, collegebound youth have largely avoided military service in the AVF era and that a draft is needed to infuse the enlisted ranks with more able personnel. Such a claim is dubious. About one-quarter of the 18-24 year-old youth population is enrolled in college. A random draft from this age group has a one-in-four chance of bringing in college students, and a very small chance of grabbing Ivy League students. However, women, who currently form 14 percent of the enlisted force, are not currently required to register with Selective Service, and so presumably would not be subject to a draft. If women were excluded from the draft, the burden of conscription would fall on the male youth population only. Nevertheless, a random draft from the full 18-24 year-old male population would subject males to less than a 1 percent chance of conscription. It is hard to imagine that politicians could justify assigning the conscription tax to such a small fraction of the youth population. A draft that attempts to maintain the current quality levels would fall very unevenly across the youth population.

In addition to how it affects the experience distribution of the force, conscription can affect the quality of new recruits, but not by attracting more high-quality, collegebound youth. We have already pointed out that a large fraction of U.S. youth does not meet current military eligibility standards. (In fact, only 26 percent does.) Of those that do not meet entry standards, 53 percent are disqualified for medical and physical reasons, 23 percent because of drugs or alcohol abuse, 12 percent for moral reasons, and the remainder for yet other reasons. Disqualifying such youth a priori would encourage malfeasance as youth attempt to avoid conscription. Some argue that drafting youth who are currently unqualified would be in those youths' interests, but it is not clear whether the military is the appropriate institution for rehabilitating such youth. How such youth would be handled under a draft is an open question, but conscripting these youth would have adverse consequences for military effectiveness.

\section{Conclusions}

U.S. military recruiting is sensitive to a number of factors, including the state of the economy, the magnitude of the recruiting effort, and, most recently, the ongoing conflicts in Afghanistan and Iraq. There is little question that the war has detracted from high-quality enlistments in the Army, although the strong civilian economy has also played a role. The Army has responded to these difficulties by boosting enlistment incentives, primarily bonuses, and by enlisting more individuals from lowquality groups. Although there has been a decline in the fraction of enlistments that are high-quality, the current level is not out of line with the high-quality intake in the mid-1980s.

Thus far, the U.S. military has successfully maintained active and reserve retention 
by a variety of inducements, including more generous reenlistment bonuses, higher pay for hazardous duty, and increased family separation allowances. However, concern remains about the future of retention if current deployment lengths are maintained.

There is little doubt that it is more costly to staff the AVF in a time of war than a time of peace - U.S. military manpower costs have risen by about $\$ 32$ billion (2005 dollars) between FY2000 and 2005, or from 0.75 percent to 0.97 percent of GDP. While the cost of military manpower is a matter of concern, the notion that personnel costs are inordinate, either in terms of the ability to pay for them or in terms of what was paid in the past, is not supported by the facts.

Conscription is not a panacea. A 25 percent increase in the size of the Army enlisted force would have little effect on manpower outlays and would detract from force effectiveness, especially if a draft compels the entry of youth who do not currently meet U.S. military entrance standards.

\section{Notes}

Curtis J. Simon and John T. Warner are at the Department of Economics, Clemson University, Clemson, SC 29634-1309, USA. They may be reached, respectively, at cjsmn@clemson.edu and jtwarne@clemson.edu.

1. See Bicksler, Gilroy, and Warner (2004).

2. See Warner and Asch (2001) for a review of the record of the AVF up to 2000.

3. In this article, years are fiscal years (FY) and run from 1 October of one year to 30 September of the next year.

\section{See Congressional Budget Office (2006, p. 30).}

5. Navy strength is planned to fall to 331,000 by 2010 and Air Force strength will decline to 320,000. These reductions are being driven in large part by technology. New classes of Navy ships that are coming on line in the near future require much lower manning levels than the classes that they are replacing.

6. During the draft era in the United States, draftees served 2-year terms.

7. These averages are from Congressional Budget Office (2006).

8. See Warner and Asch (1996) and Asch, Hosek, and Warner (2007) for reviews of formal economic models of military recruiting and retention and empirical studies of these variables.

\section{See Figure 10 of Bicksler and Nolan (2006).}

10. Emphasis on recruiting high school graduates in the top half of the mental distribution derives from the fact that they are more productive. Warner and Asch (1996) and Asch, Hosek, and Warner (2007) provide evidence on the productivity of various qualities of personnel.

11. See Warner, Simon, and Payne (2003) for estimates of the enlistment effects of veterans and college attendance using data for the period 1988-1997.

\section{Gilroy (2006)}

13. Years are fiscal years (see note 3).

14. The easier recruiting of the Air Force reflects in part the high-tech nature of Air Force training and work experience. It may also reflect better working conditions and lower exposure to danger.

15. Moreover, the labor market is forward looking. Unemployment dropped to the mid-4's by early 2006. The U.S. Navy's percent high-quality continued to increase in 2004-2005. This improvement is due to a reduction in its recruiting goal as the Navy's end strength declined.

16. Figure 2 is based on data on all active duty enlistments over the period FY19882000. Each recruit was assigned the median family income in his 5-digit zip code. Median income by zip code was obtained from the 2000 Census.

\section{Table 1-2 of Congressional Budget Office (2006).}

18. Table 1-2 of Congressional Budget Office (2006).

\section{Gilroy (2006).}

20. The Army and other services also use enlistment bonuses and college benefits to attract high-quality recruits. However, such enlistment incentives tend to be used most intensively when recruiting is particularly difficult, thus inducing a negative correlation between high-quality enlistment and the level of incentives. Correcting for such bias, called "simultaneity bias," is beyond the scope of the present analysis, and so those variables are not included as explanatory variables here. 
21. As mentioned earlier in the text, the recruiting effort also involves substantial expenditures on advertising. Unfortunately, we do not have such data available by state, information that is critical for accurate estimation of the effects of advertising.

22. Our explanatory variables control only imperfectly for the various factors that affect recruiting across states. If one assumes that the variation across states in these unmeasured factors take the form of time-invariant, state-level effects, then we can eliminate these factors by differencing the data, that is, by specifying both the dependent and explanatory variables in the form of changes rather than levels. Because there is a strong seasonal component to recruiting, we have taken fourth differences, thus differencing out any fixed, quarter-specific effects as well. Since our variables are measured in logarithms, the variables are essentially the percentage changes from their values in the same quarter in the preceding year. In the absence of time trends in the dependent variable, the intercept will drop out of a differenced model. The inclusion of an intercept allows for the existence of such a trend. Similarly, the Iraq war indicator variable, which takes on a value of one during the Iraq war and zero otherwise, measures the differential trend effect of the Iraq war. If the Iraq war had only an effect on the level of recruiting, differencing the model would require including a variable that takes on the value of one only for the period immediately following the onset of the war, for four quarterly periods, and zero both before the onset of the war and after the first year of the war.

23. The 33.7 number is arrived at by taking one-half of the "Bush pct trend" number and subtracting the "OIF period trend" number, i.e., $0.120-0.457=-0.337$, or 33.7 percent.

24. See Congressional Budget Office (2006) for details of retention trends and accomplishment of retention objectives by service.

25. Furthermore, personnel stationed in combat zones do not pay income taxes on normally taxable compensation while serving in theater.

\section{Table 2-6 of Congressional Budget Office (2006).}

27. Two compensating differentials received by personnel stationed in combat zones are Imminent Danger Pay (\$225 per month) and Family Separation Allowance (\$250 per month to married personnel who are deployed for more than 30 days).

28. Statistics available in DoD budget documents found at http://www.dod.mil/comptroller/budgetindex.html. About a third of the increase was due to implementation in 2003 of the Defense Program Health Accrual. This charge accounts for future retiree health benefits that will be paid to current military members and their families. This charge did not exist in 2001.

29. If the increase were linear, costs would rise to 1.35 percent of GDP. Two percent is surely an upper bound to allow for disproportionate pay hikes that might be required to sustain a 50 percent expansion in force size. Moreover, there is no need to expand Navy or Air Force personnel to Cold War levels. A more likely scenario is a moderate increase in Army, Marine Corps, and perhaps reserve personnel.

30. Contractor costs are part of the procurement budget and not part of the manpower budget as normally defined. DoD can substitute private contractor services for military personnel, which it did a lot of in Bosnia where food and housing services were contracted out rather than provided by military cooks or construction workers. It can also substitute government civilian employees for uniformed military personnel. Again, the cost of civilian employees shows up in other parts of the DoD budget.

31. The Army reported an average initial training cost of \$16,800 in 2004.

32. For a full elaboration of the difference in opportunity costs between volunteer and conscripted forces, see Warner and Negrusa (2005).

33. When the demand for military manpower exceeds a certain threshold, it is possible for the social cost of a volunteer force to exceed the cost of a conscripted force. See Warner and Negrusa (2005) for details. Our calculations indicate that the threshold is likely to occur at a much larger force level than the ones contemplated above.

\section{References}

Asch, B., J. Hosek, and J. Warner. 2007. "The New Economics of Manpower in the Post-Cold War Era,” in K. Hartley and T. Sandler, eds. Handbook of Defense Economics, volume 2. Amsterdam: Elsevier.

Bicksler, B., C. Gilroy, and J. Warner. 2004. The All-Volunteer Force: Thirty Years of Service. Washington, DC: Brassey's.

Bicksler, B. and L. Nolan. 2006. Recruiting an All-Volunteer Force: The Need for Sustained Investment in Recruiting Resources. Washington, DC: Strategic Analysis, Inc.

Gilroy, C. 2006. Recruiting an All-Volunteer Force: What Does Enlistment Supply Look Like? Briefing dated 2 November. Washington, DC: Office of the Undersecretary of Defense (Personnel and Readiness).

Poutvaara, P. and A. Wagener. 2007. “Conscription: Economic Costs and Political Allure.” Economics of Peace and Security Journal, Vol. 2, No.1, pp. 6-15.

United States Congressional Budget Office. 2006. Recruiting, Retention, and Future Levels of Military Personnel. Publication 2777. Washington, DC: Congressional 


\section{Budget Office.}

Warner, J. and B. Asch. 1995. “The Economics of Military Manpower,” pp. 347-398 in K. Hartley and T. Sandler, eds. Handbook of Defense Economics, volume 1. Amsterdam: Elsevier.

Warner, J. and B. Asch. 2001. "The Record and Prospects of the All-Volunteer Military in the United States.” Journal of Economic Perspectives, Vol. 15, pp. 169-192.

Warner, J. and S. Negrusa. 2005. "Evasion Costs and the Theory of Conscription.” Defence and Peace Economics, Vol. 16, pp. 83-100.

Warner, J., C. Simon, and D. Payne. 2001. Enlistment Supply in the 1990s: A Study of the Navy College Fund and Other Enlistment Incentive Programs. Report No. 2000-015. Arlington, VA: Defense Manpower Data Center.

Warner, J., C. Simon, and D. Payne. 2003. "The Military Recruiting Productivity Slowdown: the Roles of Resources, Opportunity Cost, and Tastes of Youth.” Defence and Peace Economics, Vol. 14, pp. 329-334. 